Paweł Mielcarz ${ }^{*}$ Paweł Paszczyk ${ }^{* *}$

\title{
Increasing Shareholders Value through NPV-Negative Projects
}

Submitted: August 23rd 2010

Accepted: September $22^{\text {nd }}, 2010$

\section{Summary}

The concept of Net Present Value (NPV) is a widely accepted tool for verification of financial rationality of planned investment projects. Projects with positive NPV increase a company's value. Similarly, those with negative NPV lead to a decline in the value of a business. This article attempts to answer the question: are projects with negative NPV always disadvantageous in terms of maximization of shareholder value and when should an NPV-negative project be considered justified?

The authors discuss the issues of project valuation depending on different conditions. First, they briefly summarize the main idea of valuation - the aim of every company is to maximize shareholder value. Contemporary professional texts say that the way to achieve this goal is through projects that can generate a positive Net Present Value. When there are no such investments within reach, the company should pay dividends to its owners. The authors claim that some circumstances justify investments with a negative Net Present Value, as they still produce maximum possible shareholder value. The three model situations where this takes place are: (1) tax on dividends; (2) shareholders' perception of risk; and (3) temporary inefficiency of the markets.

Taxes on dividends reduce cashflows for shareholders from distributed dividends. Therefore, they act exactly as an investment with a negative NPV. The authors conclude that this creates an opportunity to maximize shareholder value by comparing this loss with available alternate projects with negative NPV. If the loss of worth, caused by such taxes, is bigger that the negative NPV of possible investments it will be more rational to

${ }^{*}$ Dr, adiunkt, Akademia Leona Koźmińskiego w Warszawie.

${ }^{* *}$ Mgr, DCF Consulting Sp. z o.o. 
invest instead of paying dividends. And, according to the authors, a project with a negative NPV leads to maximized shareholder value.

In the second situation, the authors point out that some projects may have negative fundamental (intrinsic) value when valuated by the market (diversified owners) because of their higher expected rate of return. In the same circumstances, an undiversified shareholder may have a different perception of the investment. It is highly possible that he would be ready to accept a lower rate of return in exchange for more safety for his capital. The authors conclude that negative fundamental value (based on the market situation) may be of importance for such shareholder as he prefers projects with lower risk and a lower rate of return.

Temporary inefficiencies of the markets may produce a risk of bankruptcy or liquidity problems. The authors argue that NPV-negative projects may be a way to free additional cashflows, which will allow the financial restructuring of the company.

\section{Introduction}

The generally accepted theory of corporate finance posits that an investment project will translate into higher shareholder value (SV) if it generates a positive Net Present Value (NPV). From the perspective of a company's owners, projects with a negative NPV are economically irrational, as they lead to a decline in their wealth. However, the authors of this text believe that there are some exceptions to that rule. The next sections present three cases where opting for an NPV-negative project is an optimum choice to maximize shareholder value.

\section{Acceptance of NPV-Negative Projects and Tax on Dividends}

The theory of residual dividend, formulated for the first time by G. Preinreich (Preinreich, 1932: 273-289), indicates that a company should distribute its free funds (cash surplus) to its owners (as dividends or other distributions to shareholders, e.g. repurchase of shares or cost-based transfers that are actually cash distributions to owners (Mielcarz, 2009: 97-119)) after financing all available projects with a positive NPV (Baker, Smith, 2006: 1-2). In accordance with this concept, free cash flow that is left in a company and are not allocated to projects that offer a return above a level required by capital providers will lead to the ineffective utilization of capital, which should translate into a decline in the price of shares of such company ${ }^{1}$. And if the course of action is taken in line with the residual dividends theory, the price of shares will drop by the amount paid to the investors, but from the perspective of the shareholder value this decline will be

\footnotetext{
${ }^{1}$ A situation where the rate of return expected by an investor exceeds the rate of return earned by the company on its investment projects leads to a negative NPV and, thus, to a decline in the price of its shares. One may ask here about the perception of risk for various investors and, consequently, the mechanisms they use to estimate expected returns. This issue, and its impact on the estimations of NPV of various projects, is discussed in detail in the second part of this article.
} 
compensated by an increase in cash in their private accounts. Therefore, if dividends are not taxed, transfers of cash to owners are neutral for their wealth ${ }^{2}$.

Some authors point out that the fact that a company has some free funds that will not be allocated immediately to any specific project will not necessarily lead to an automatic decline in the shareholder value, provided that the company decides to use an option to defer a project in time until the optimum moment comes for the implementation of an NPV-positive project e.g. takeo-ver of another company (Trigeorgis, 1995: 5). However, it may also be assumed that in such situations decision-makers take into account the expected NPV of the project (weighted with the probability of the actual implementation of the project), i.e. their behavior is in accordance with the residual dividend theory.

The analysis of the assumptions of the residual dividend theory and of the concept of maximization of shareholder value bears a question about the universality of the thesis which posits that the only rational way, from the perspective of financial interests of a company's owners, is either to implement projects that offer a positive NPV or to distribute any free cash to them in absence of such projects. The example below shows that if tax on dividends is included in such analysis, the statement formulated as above must be verified.

\section{Example 1}

The market capitalization of a company (E) is 1000 currency units (c.u.) at a moment of time assumed as point zero. The company has 100 c.u. in free funds, which it may use to finance some investment projects. On the basis of currently available information, investors expect that those funds will be allocated to an investment project with NPV = 0 . After an in-depth analysis, the company's board concludes that the project may generate actual positive free cash flows having their present value (PV) at the level of 81 c.u., while necessary expenditures (PVI) amount to 100 c.u. In the country where the company operates capital gains are subject to a $19 \%$ tax rate, if it is paid as withholding tax on dividends, while in the case of an increase in the price of shares such tax is paid after shares are sold, and only if the investor realizes a gain. The available information is summarized in Table 1.

What steps should be taken in that situation to maximize shareholder value? In accordance with the residual dividend theory, the project should be dropped, as having a negative NPV, and dividends should be paid to the shareholders, since that concept says that if there are no NPV-positive projects, the maximization of shareholder value is tantamount to the reduction of its decline. However in order to verify whether such

${ }^{2}$ Contrary to the fundamental approach, some empirical researches confirm the hypothesis of the signaling effect of dividend announcements (Michaeley, Thaler, Whomack, 1995: 573-608). They indicate that share prices respond positively to information on higher than expected or previously unexpected distributions of dividends. This is because the market is adjusting the share valuation level to new information, which was previously available only to managers, as management's recommendation to pay higher than expected dividends is a signal for investors that the financial situation of the company is better than previously assumed. Therefore, the researches that confirm the signaling effect hypothesis as viable also challenge the classic theorem that dividends do not affect shareholder value. 
Table 1. Example 1 - initial data

\begin{tabular}{|l|c|c|}
\hline $\begin{array}{l}\text { Value of shares before decision, including free cash that may be used either for } \\
\text { investments or for dividends }\end{array}$ & $\mathrm{E}_{0}$ & 1000 \\
\hline Free cash for investments or distributions to shareholders & $\mathrm{PVI}$ & 100 \\
\hline Present value of available investment projects & $\mathrm{PV}$ & 81 \\
\hline Net present value of available investment projects & $\mathrm{NPV}$ & -19 \\
\hline
\end{tabular}

Source: own study.

scenario is rational, it is worth calculating final shareholder value in both scenarios, i.e. the distribution of dividends and the execution of the NPV-negative project. In the 'with-dividends' variant, shareholder value should be calculated as follows ${ }^{3}$ :

$$
S V_{\mathrm{D}}=E-D+C_{\Delta}
$$

[Formula 1]

where: $S V_{\mathrm{D}}$ - total shareholder value in the 'with-dividends' scenario; $D$-dividends paid by the company; $C_{\Delta}$ - increase in balances in the accounts of shareholders due to the distribution of dividends, which is calculated with the following formula:

$$
C_{\Delta}=D \times\left(1-t_{D}\right)
$$

[Formula 2]

where: $t_{\mathrm{d}}$ - rate of tax on dividends.

$$
\begin{gathered}
S V_{\mathrm{D}}=1000 \text { c.u. }-100 \text { c.u. }+100 \text { c.u. } \times(1-0,19) \\
\boldsymbol{S} \boldsymbol{V}_{\mathbf{D}}=\mathbf{9 8 1} \text { c.u. }
\end{gathered}
$$

In the scenario assuming the implementation of the NPV-negative project, shareholder value will be calculated with the following formula:

$$
S V_{\mathrm{P}}=E+N P V
$$

where: $S V_{\mathrm{P}}$ - shareholder value in the 'with-project' scenario; $N P V$ - net present value of the examined project.

$$
\begin{gathered}
S V_{\mathrm{P}}=100 \text { c.u. }+(-19) \text { c.u. } \\
\boldsymbol{S} \boldsymbol{V}_{\mathbf{P}}=\mathbf{9 8 1} \text { c.u. }
\end{gathered}
$$

In this example, the implementation of the project with its NPV higher than -19 c.u. will give shareholder value higher than the distribution of dividends. This example shows that when tax on dividends reduces shareholder value more than a project that generates a negative NPV, the company should opt for the NPV-negative project. It means that -

${ }^{3}$ Assuming that only fundamental factors affect shareholder value and that dividends create no positive signaling effect. 
from the perspective of shareholder value - an NPV-negative project may be better justified than the distribution of free funds as dividends. Such solution is optimal in a situation where tax paid on dividends should exceed the decline in the price of shares resulting from the execution of an NPV-negative project.

This relationship may be presented as the following general equation:

$$
\text { If: } t_{D}=>\mathrm{SV}_{\max }=E+N P V^{-}
$$

[Formula 4]

where: $S V_{\max }$ - maximum shareholder value at a given moment.

It should be noted that the decision to execute an NPV-negative project, as described above, is also optimal if capital gains are taxed. Such tax liability may only occur when the price of shares goes up. If we omit behavioral finance arguments and assume the market is fully efficient, the price of shares may only grow as a result of NPV-positive ventures. So, if the company from the example implements projects that generate NPV in the range from -19 to 0 , its shares will not rise, and, no tax on capital gains will be due. In turn, if NPV for a project is positive, the increase in the value of shares will be reduced by capital gains tax, which, however, will only be payable on the surplus, i.e. NPV for the project. Consequently, a decision to execute a project will always maximize shareholder value for NPV equal to or higher than -19 c.u.

The above example may be the base for a more general residual dividend theory. If tax on dividends is taken into account, the theory should be formulated as follows: in a situation of limited availability of NPV-positive projects, a company that applies the concept of maximization of shareholder value should implement all projects with a positive NPV and those NPV-negative projects that lead to a lower decline in the price of its shares than the loss of shareholder value resulting from the need to pay tax on dividends.

\section{Risk Perception, Fair Value and Net Present Value}

The fact whether a given project creates positive shareholder value or not depends, to a large extent, on the rate of return expected by shareholders. It seems that the expected return parameter is subjective and, hence, a project may have different NPVs for investors who formulate different assessments of project-related risks. However, the theory of finance provides some clues how to determine a minimum expected return from the perspective of a company's shareholders that would be justified in the context of assumed risk. The determination of such rate should lead to the estimation of the "objective", or fair, value of a project. To determine its level, the assumptions of the Fair Value Theory, the Portfolio Theory and the Capital Asset Pricing Model should be analyzed in more detail. If the level of the "objective" expected rate of return is determined, this will allow for presenting arguments in favor of the thesis that the execution of projects that generate a lower rate of return may be a rational choice from the perspective of the financial interests of shareholders. 
The theory of finance employs various concepts of value. No doubt, the fair value concept is considered one of the most important at present (Pratt, Niculita, 2008: 41-47). IAS 39, 40 and 41 and IFRS 3 provide that the market price, quoted in an active market, is the most accurate reflection of the fair value of a given asset. In accordance with the above standards, if there is no active market for a given asset, the assessment of its fair value should refer to a situation as if a hypothetical transaction in an active market were completed. In addition, IAS 38.7 points to liquidity as one of the key attributes of an active market, which in practice is tantamount to the assumption of an unlimited number of investors who are potentially interested in the purchase or sale of a given asset.

The assumption of an unlimited number of buyers and sellers is fundamental for determination of the expected rate of return (discount rate) that could be used for valuation of assets unlisted in an active market in accordance with the fair value standard. The above assumption leads to the conclusion than the "objective" rate of return should be insensitive to the liquidity level of a given asset, as a fully active market creates no liquidity problems. However, since the presence in such market of investors who diversify their risk in accordance with the assumptions of the portfolio theory of H. Markowitz (Markowitz, 1952: 77-91) cannot be ruled out, the rate that would allow for determination of fair value of a given asset (including an investment project) should neither include a premium for specific risk (Sharpe, 1964: 425-442). If specific risk is eliminated, the rate of return on investments in a given asset that is expected by the owners would lower to a level reflecting their systematic risk, a premium for investing in equity instruments and a risk-free rate ${ }^{4}$. The assumptions of existence of an active market and of a possibility to reduce specific risk by diversification of an investment portfolio, and, consequently, the justification of a premium on capital at the level of systematic risk related to a given asset only are fully in accordance with the assumptions of the Capital Asset Pricing Model (CAPM). Therefore, there are arguments in favor of the conclusion that the CAPM is a suitable tool for determination of the objective rate of return expected by shareholders, which allows for estimations of fair value of not only equity instruments, but also investment projects in an inactive market. If the managers of a company accepted a project with a rate of return below the level resulting from the CAPM, the capitalization of such company in an active and fully-informed market would immediately slump by the negative NPV of such project. That's why a company that has a diversified shareholder base and operates in accordance with the shareholder value maximization concept should reject projects that create a rate of return lower than the return estimated with the use of the CAPM. Figure 1 summarizes the above line of reasoning.

A decision on whether or not to execute a project and on its impact on shareholder value becomes more complicated when shareholders do not apply the concept of diversification to their investment portfolios. This is the case, for example, when an investor holds $100 \%$ of shares in a given company and has no other significant assets,

\footnotetext{
${ }^{4}$ It should be noted here that in the real life in a perfectly active market investors who reduce the specific risk of an investment by diversification accept the lowest expected rates of return, and, thus, the highest transaction prices. So, it is this group of investors that imposes the terms of buying on the other participants of an active market.
} 
Figure 1. Justification of use of the CAPM for estimates of the expected rate of return for the purposes of fair-value valuation

\section{Concept of fair value estimates}

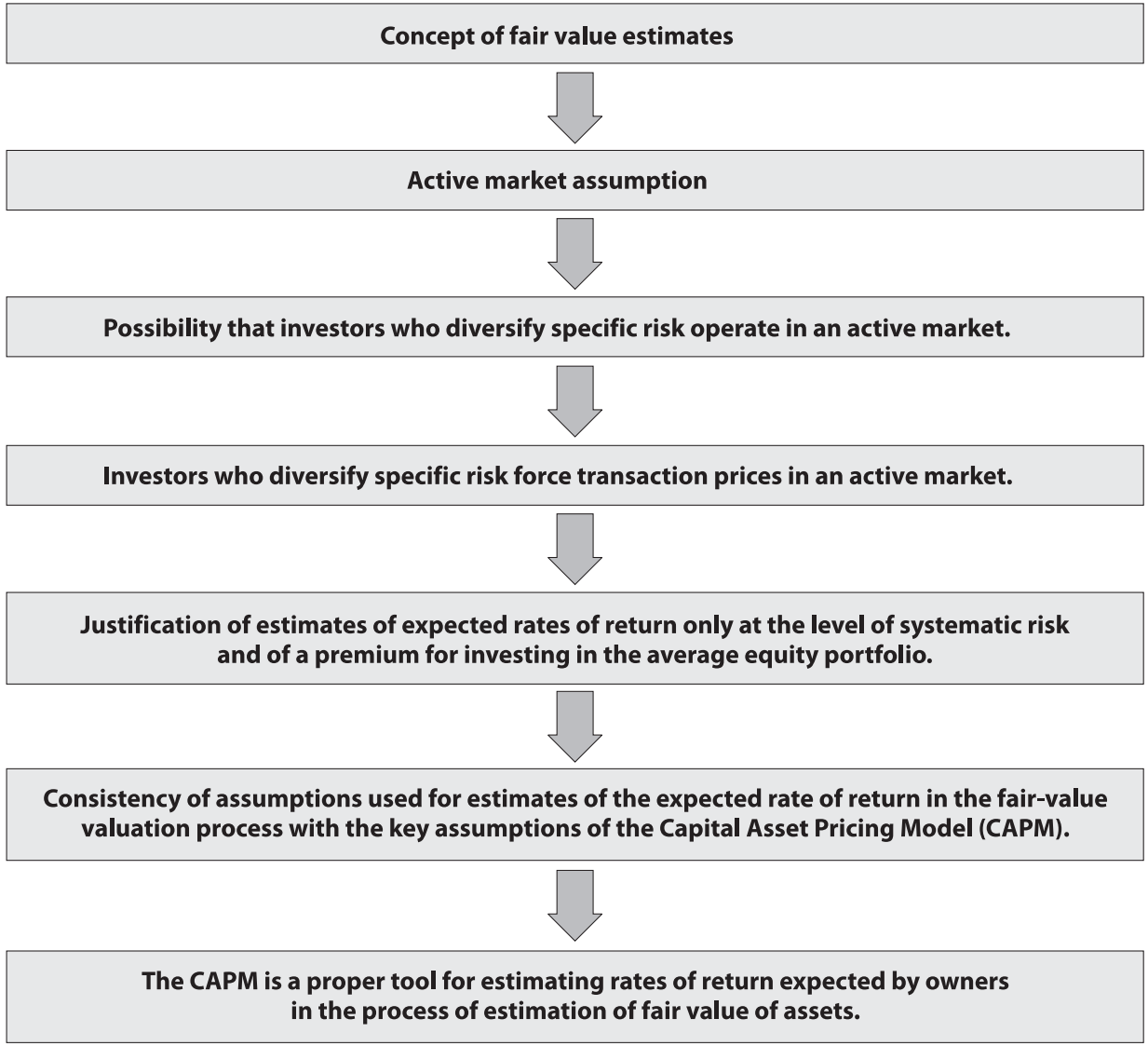

Source: own study.

except those shares. In such a situation, the company is the investment platform of its owner, used not only for value management, but also to diversify the private investment portfolio. For the owner's wealth and risk level, it could be rational to adopt a strategy under which the company accepts projects that do not generate the "objective" fair rate of return, but, despite this, still reduce the level of the owner's private risk. Such situation is presented in Example 2.

\section{Example 2}

ABC Company is examining a streamlining project that is to reduce operating expenses as a result of purchase of more advanced machinery for manufacturing operations. The project should generate the following fee cashflow for equity (FCFE): 
Table 2. Example 2 - initial data

\begin{tabular}{|l|c|c|c|c|}
\hline Year & 0 & 1 & 2 & 3 \\
\hline FCFE & $-10,0$ & 5,0 & 3,5 & 3,0 \\
\hline
\end{tabular}

Source: own calculations.

The company is listed in an active stock exchange market and its shareholders structure is diversified. For the current owners, ABC shares are only marginal parts of their investment portfolios. The shareholders make their investment decisions in line with the portfolio theory standards. In addition, there is no problem to sell shares at no cost. The rate of return excepted by capital providers, estimated with the CAPM, is $11 \%$. Will this project increase shareholder value?

In the above circumstances, the current shareholders will expect the minimum rate of return at the level of $11 \%$. This value represents the expected rate of return on investments in the company's shares in accordance with the assumptions of fair value estimates. To follow the concept of maximized shareholder value, the company should not start any project with a lower rate of return.

For the expected return of $11 \%$, the project create a negative NPV of (-) 0.46 million c.u., so its execution would lead to a decline in the capitalization of the company and, as a result, of shareholder value. The calculations are presented below:

Table 3. Example 2 - Project assessment from the perspective of the diversified shareholders

\begin{tabular}{|l|c|c|c|c|}
\hline Year & 0 & 1 & 2 & 3 \\
\hline FCFE & $-10,0$ & 5,0 & 3,5 & 3,0 \\
\hline DFCFE & $-10,0$ & 4,6 & 3,0 & 2,4 \\
\hline NPV & $-\mathbf{0 , 5}$ & & & \\
\hline
\end{tabular}

Source: own calculations.

The calculations show that if the company wants to protect the interests of the diversified shareholders it should abandon the project. However, one should ask here about the assessment of the project if the conditions of estimates of fair value were not met, i.e. assuming the non-existence of conditions under which the investors perceive risk in accordance with the CAPM.

\section{Example 2 continued}

Let's assume that one investor holds $100 \%$ of shares in ABC Company and that all his assets are invested in that company, which means that the owner's investment portfolio is not diversified. Such investor has high risk aversion and prefers safe investments, which will protect the value of his assets and reduce the risk connected with the company's operations. From his perspective, the above investment meets such condition. Reduced risk appetite lowers the owner's expected rate of return on the market-risk-free 
streamlining investment below the level of the "objective" rate, calculated from the perspective of diversified minority investors. For the undiversified investor it equals $7 \%$. On that basis, the NPV of the project may be estimated for the owners holding all the shares of the company:

Table 4. Example 2 - Project assessment from the perspective of the undiversified shareholder

\begin{tabular}{|l|l|l|l|l|}
\hline Year & 0 & 1 & 2 & 3 \\
\hline FCFE & $-10,0$ & 5,0 & 3,5 & 3,0 \\
\hline DFCFE & $-10,0$ & 4,7 & 3,1 & 2,4 \\
\hline NPV & $\mathbf{0 , 2}$ & & & \\
\hline
\end{tabular}

Source: own calculations.

The above shows that a change of risk perception, and, thus, the expected rate of return, leads to a situation where a project can generate positive shareholder value despite negative fair value. From the perspective of a single investor (if his asset portfolio is not diversified) it is possible that he will not always determine expected rates of return in accordance with the fair value concept.

A similar divergence between NPVs of a project for diversified investors and for an undiversified investor may occur for higher-risk ventures. In such a case, diversified investors would estimate their expected rates of return on the basis of assessments how a given project increases only the systematic risk of investing in given shares. And the undiversified investor would be sensitive to all risks, so he would add a premium for specific risk to the expected rate of return on a project. Differences between expected rates of return may lead to different calculations of NPVs - even if a project may create a positive NPV for diversified investors, who estimate its fair value, the same project could be financially unreasonable for an investor who is sensitive to its specific risk.

To recapitulate the above discussion, it should be concluded that it is possible that an undiversified investor will opt for the execution of a project despite its negative fair value or for the rejection of a project with positive fair value.

\section{Acceptance of NPV-Negative Projects and Protection of Financial Liquidity}

The acceptance of NPV-negative projects may also maximize shareholder value where an alternate scenario leads to the loss of financial liquidity or forces the liquidation of a company. It is possible during periods of temporary inefficiency of financial markets and of tangible asset markets. By choosing an NPV-negative project, shareholders buy time and funds that are necessary to initiate corrective actions to avoid a further deterioration of the company's financial standing. The next example presents such a situation: 


\section{Example 3}

ABC Company (real estate developer) bought an undeveloped property for 10 million c.u. two years ago. Its current value in the market is 2 million c.u. However, the market does not comply with the active market definition as a result of the recent panic escape of investors from the investment real property segment, coupled with a surplus on the supply side in the land market caused by a deteriorating financial situation of many developers. Many experts believe the capital outflow is only temporary and real estate prices should recover to the previous level in the next few years. In such circumstances the fair value of the plot was assessed at 9 million c.u. ABC Company has now some financial problems. Analyses show that if it built and sold apartments on the subject plot, the NPV of the project would be negative - at a level of 3 million c.u., assuming that the initial expenditures would include the real property valued at 9 million c.u. as contribution in kind. In addition to the higher fair value of that real property, the negative NPV is also an effect of lower apartment prices accepted by end buyers. The detailed calculations for the project are included in Table 5:

Table 5. Example 3 - Calculations of NPV for the housing development project of ABC Company

\begin{tabular}{|l|c|c|c|c|}
\hline Year & 0 & 1 & 2 & 3 \\
\hline FCFE (investement expenditure excluded) & & 4.2 & 2.7 & 2.7 \\
\hline Project expenditures to be covered from the company's own resources & & -2.0 & & \\
\hline Fair value of the plot (contribution in kind) & -9.0 & & & \\
\hline FCFE for NPV calculations & -9.0 & 2.2 & 2.7 & 2.7 \\
\hline Expected fair value rate of return & $12 \%$ & & & \\
\hline Discounted FCF & -9 & 2.0 & 2.1 & 1.9 \\
\hline NPV & $-\mathbf{3 . 0}$ & & & \\
\hline
\end{tabular}

Source: own calculations.

Because of the difficult situation of the ABC company, its management takes into account not only the maximization of value, but also changes in cash balance as a result of the project. If the company fails to ensure new inflows of cash, it may lose its ability to serve and repay loans taken in the past for real estate purchases. From such perspective, the project looks attractive: ABC would increase its cash by 2,2 million c.u. in Year 1 and by 2,7 million c.u. in Year 2 and 3. As a result, it would recover part of the capital frozen in the financing of the property to be contributed in kind into the project. As already mentioned, an alternative scenario to improve liquidity could be the sale of the plot for 2 million c.u., but it would not be optimal both in terms of value (NPV $=-7$ million c.u.) and in terms of liquidity protection (a considerably lower inflow of cash).

In this example, the execution of the NPV-negative project is optimal for shareholder value. A keep-waiting scenario, i.e. postponing the project until the fair value of the plot reaches the level of its market price (which would also mean an increase in apartment prices) will most likely lead to the continued deterioration of the company's financial 
situation, and even its bankruptcy, which would inevitable slash down shareholder value. The company has no other options to get capital, except for releasing cash frozen in illiquid assets. Therefore, one may conclude that when a company needs capital while its financial situation is deteriorating the financial restructuring by execution of NPV-negative projects could maximize shareholder value.

\section{Conclusions}

This article was intended to present some situations when an NPV-negative project could be the right choice to maximize shareholder value. There is a consensus that if a company lacks projects that would generate positive NPV, it should allocate its free cash to dividends. However, the situation turns out to be more complex if dividends are taxed. For shareholders, it is the same as if the project's NPV was negative. In such case, a project with an insignificant negative NPV can be used to maximize shareholder value. If the company can execute a project whose absolute NPV is greater than tax on dividends, its implementation would maximize shareholder value.

The same investment project may have different NPVs for various investors. The main reason is different expected rates of return of shareholders who diversify their risk by investing in many different financial instruments and shareholders who are sensitive to total risk. Differences in risk perception may lead to situations where low-risk and low-return projects are rejected by diversified investors, but accepted by shareholders who are searching for options to diversify their private assets through low-risk projects. The same reason also explains different behaviors when a high-return and high-risk project is welcomed by diversified investors, but unacceptable for undiversified ones.

The third situation described here is connected with the need to execute an NPV-negative project to rescue the company. In this case, an NPV-negative project usually is to release new cashflows to eliminate temporary liquidity shocks and, as a result, to create the environment in which the business will keep going on and can be restructured.

\section{References}

Baker H.K., Smith T.D.M., In search of a residual dividend policy, "Review of Financial Economics", 15, 2006.

Trigeorgis L., Real Option in Capital Investment-Models, Strategies, and Application, Praeger, Londyn 1995.

Michaely R., Thaler R.H., Womack K.L., Price reactions to dividend initiations and omissions: Overreaction or drift?, "Journal of Finance", 50, 1995.

Mielcarz P., Przepływy ekskluzywne a metody wyceny akcji wchodzacych w sklad pakietów kontrolnych i niekontrolnych, „Bank i Kredyt”, 40 (2), 2009.

Pratt S.P., Niculita A.V., Valuing a Business. The Analysis and Appraisal of Closely Held Companies, McGraw Hill, New York 2008.

Preinreich G.A.D., Stock yields, stock dividends and inflation, "The Accounting Review”, 7, 1932.

Sharpe W.F., Capital asset prices: A theory of market equilibrium under conditions of risk, "Journal of Finance", 19 (3), 1964. 


\section{Podnoszenie bogactwa właścicieli poprzez realizację projektów o ujemnym NPV}

\section{Streszczenie}

Koncepcja wartości aktualnej netto (NPV) jest powszechnie przyjętym sposobem określania racjonalności planowanych przedsięwzięć inwestycyjnych. Projekty o dodatniej NPV generuja wzrost wartości firmy. Analogicznie, projekty o ujemnym NPV powoduja spadek wartości przedsiębiorstwa. W artykule podjęto próbę odpowiedzi na pytanie, czy podjęcie działań o ujemnym NPV jest zawsze niekorzystne z punktu widzenia maksymalizacji wartości bogactwa dla wtaścicieli oraz w jakich sytuacjach podjęcie projektów o ujemnej wartości aktualnej netto jest racjonalne.

Zgodnie z teoriq dywidendy rezydualnej przyjmuje się, że w przypadku braku projektów o dodatniej wartości aktualnej netto, przedsiębiorstwo powinno wypłacić nadwyżkę środków finansowych jako dywidendę. Sytuacja komplikuje sięjednak, gdy konieczne jest zapłacenie podatku od dywidend. Z punktu widzenia właścicieli nie różni się on niczym od projektu o ujemnym NPV. W takim wypadku zamiast wypłaty dywidendy, możliwe jest wykorzystanie projektu o niewielkim ujemnym NPV do maksymalizacji wartości dla właścicieli. Jeśli przedsiębiorstwo może zrealizować przedsięwzięcie o bezwzględnej wartości NPV większej niż wartość podatku od dywidend, przeprowadzenie takiego projektu doprowadzi do maksymalizacji wartości dla właścicieli.

Ten sam projekt inwestycyjny może charakteryzować się różnq wartościq aktualna netto dla różnych inwestorów. Wynika to z faktu, że właściciele dywersyfikujacy ryzyko poprzez inwestycję w różnorodne instrumenty finansowe określaja inaczej oczekiwanq stopę zwrotu niż inwestorzy wrażliwi na ryzyko calkowite. Różnice w postrzeganiu ryzyka mogę doprowadzić do sytuacji, w której nisko ryzykowne i generujace niewielka stope zwrotu projekty będq odrzucane przez inwestorów zdywersyfikowanych a zarazem akceptowanych przez właścicieli poszukujacych możliwości dywersyfikacji prywatnego majatku poprzez nieryzykowane projekty. Ta sama przyczyna tłumaczy odmienne postępowanie w sytuacji, gdy projekt wysokorentowny i ryzykowny jest dobrze oceniany przez inwestorów zdywersyfikowanych, ale odrzucany przez inwestora niezdywersyfikowanego.

Trzecia opisana, sytuacjajest konieczność realizacji projektu o ujemnym NPV w celu zapewnienia dalszego funkcjonowania przedsiębiorstwa. W takim przypadku projekt o ujemnym NPV prowadzi najczęściej do uwolnienia nowych przepływów pieniężnych, które pozwola przeciwdziałać chwilowym zaburzeniom plynności firmy, a tym samym zapewniq jej dalsze funkcjonowanie i umożliwiq restrukturyzację finansowq. 